\title{
Winter Records of Bats in Saskatchewan
}

\section{R. W. Nero, Saskatchewan Museum of Natural History}

There are few winter records of bats in western Canada although they have been found as far north as Alaska (Mossman, A.S., and W. $\mathrm{K}$. Clark, 1958. Winter records of bats in Alaska. Journ. Mamm., 39: 585 ). Some of our bats migrate to warm regions for the winter (e.g., Red Bat and Silver-haired Bat), but others go into hibernation in suitable caves and mines. No caves are known in southern Saskatchewan but it would be expected that bats would hibernate in some of the coal mines in the south. In March, 1957, a group from the Museum (R. Fyfe, B. McCorquodale, A. Swanston and the author) visited several mines in the Estevan region (Long Creek valley). This trip was briefly noted in the Blue Jay, 15:65-67, but the details were not recorded. At that time we explored several horizontal mine shafts without finding any bats, but following the advice and direction of Mr. E. Tajc, owner and operator of a mine five miles southwest of Estevan, we were able to find a few. On March 15, 1957, we found 13 hibernating bats in several drill-holes of about two inches diameter remaining in the walls of a nearby old abandoned coal mine. The bats were collected with the aid of a flashlight and a long wire "grapple". We found eight Little Brown Bats (Myotis lucifugus) (one male, seven females) and five Big Brown Bats (Eptesicus fuscus) (one male, four females). Up to five bats were found in a single hole, but not in mixed lots. So far as I can determine, this is the only record of hibernating bats in Saskatchewan. Other bats may be expected in similar situations in the southern part of the province, and we would be interested in hearing from anyone who may know about such places.

Occasionally bats are found in the winter in situations where hibernation would seem difficult, owing to an apparent lack of certain temperature and humidity requirements, and it is difficult to explain their survival. Nearly every year, for example, a few Big Brown Bats are found in Regina, usually in heated buildings where they are seen suddenly flying about. Specimens have been collected in Regina as follows:

October 10, 1956-Female.

October 22, 1956-Male.

October 29, 1913-Male.

November 17, 1958-Female.

November 29, 1956-Female.

February 7, 1957-Female.

February 23, 1928-Male.

March 15, 1956-Male.

So far as 1 can determine no other species has been recorded in the province during this period of fall and winter. Our recent record is of special interest because it is apparently the most northern winter record for Saskatchewan. A female Big Brown Bat was found alive in a building at Prince Albert about February 1, 1959, by Mr. A. Ball. We are indebted to Miss Connie Pratt, Provincial Health Laboratory, Regina, for supplying the specimen and this information. No doubt these winter records tend to confuse the migration picture but observations of free-flying bats in fall and winter should be recorded. Such records are rare and seldom identified to species but provide clues to (Continued on page 84)

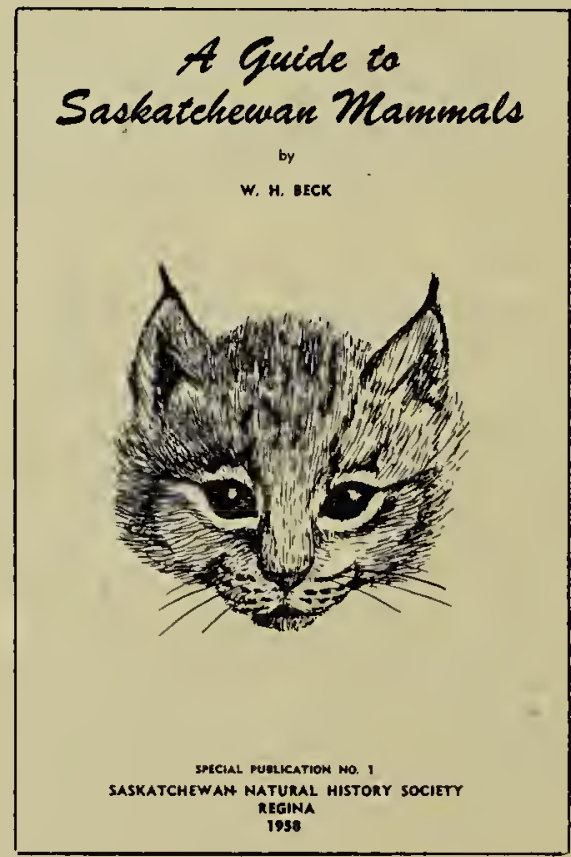

By W. H. Beck

Special Publication No. 1 Saskatchewan Natural History Society 50 cents from the Treasurer E. L. Fox, 1053 Gladmer Park, Regina. 
to giving general information about skates, the article informs the reader about a public aquarium. A series of articles such as this dealing with aquaria, natural history museums, zoological gardens, etc., across the country would be profitable. A directory of such places could be included in each issue for the benefit of readers who are travelling and want to know where such places are located.

The Audubon Junior's section has stories especially for children, and in the March-April issue there are suggestions for the teacher on how to use articles throughout the issue. Teachers and other group leaders who are involved in teaching nature science will find this magazine a valuable teaching aid.

The articles in Canadian Audubon are well written and not too technical. They provide a wealth of information on many aspects of wildlife from the housekeeping activities of ants to a discussion of the unreasoning fear many people have of snakes. In the latest issue there is an article on astronomy, "Stars with Tails," and one dealing with the plant kingdom, "Miracle of the Swamplands." This should indicate the wide range of subject matter which is covered.Joyce Dew, Saskatchewan Museum of Natural History.

Western Grebe Colony. By Robert W. Nero, photographs by Fred W. Lahrman. Natural History, LXVIII: 291-294, May, 1959.

During the summers of 1956 and 1957 a colony of Western Grebes nesting on dry land on the Isle of Bays in Old Wives' Lake southwest of Moose Jaw was studied by a party from the Saskatchewan Museum of Natural History. The valuable observations made at this time of the first dry-land nest site reported for the Western Grebe were published in the Auk, 75:347-349, 1958 (Cf. Blue Jay, $16: 185-6,1958)$. Now the behavioural aspects of this study are presented in an article of a more popular nature appearing' in Natural History (published by the American Museum of Natural History, New York). Lavishly illustrated (ten black-andwhite photos and one full-page colour plate), this article describes in a readable style the courtship and nesting behaviour of breeding Western Grebes observed in the Isle of Bays colony. A good deal of the enthusiasm of the observer is conveyed by Dr. Nero, and he makes the reader feel that watching the behaviour of the grebes, in addition to contributing valuable information for their research study, was an exhilarating experience in itself.-M.B.

Biological Research in Conversation. Special issue of the Bulletin for Medical Research (Vol. 13, No. 1, Jan.-Feib., 1959), published by the National Society for Medical Research, Chicago.

An unusual issue of the Bulletin for Medical Research has come to the editor's desk. It is an issue devoted entirely to a symposium entitled "Biological Research in Conservation," and it should be of great interest to all natural history students concerned about sound conservation policies and practice.

Since public conservation policy is often based on popular misconceptions rather than on the established findings of biological research, this journal (founded to encourage research in the biological and medical sciences) feels that it is important to clear away some of these long-established popular prejudices. Accordingly, five of the foremost conservation scientists in the United States have been asked to contribute to this special issue. Perhaps the name best known to us is that of Durward $L$. Allen, who writes of "Conservation Biology-Facts and Fallacies." Mr. Allen is concerned to show, as he did so effectively in his Wildlife Legacy, the lack of wisdom in certain socalled "conservation" practices such as the artificial stocking of game and fish, the over-protection of game species like deer in areas where overpopulation will destroy their natural habitat, and the control of predators by the bounty system. Copies may be obtained at 25 cents per issue from The National Society for Medical Research, 920 South Michigan Blvd., Chicago 5, Illinois.-G. F. L.

(Continued from page 78)

the migratory habits of these interesting mammals. Thanks to Mrs. D. Sutton, Rocanville, we have an early spring record for the Little Brown Bat, one of which she found drowned in a rain barrel on May 5 , 1958. This is the earliest record we have for this species. 